\title{
Prevalence of Coronary Heart Disease with Risk Factors History of Hypertension and Diabetes Mellitus at the Regional Government Hospital dr. Zainoel Abidin in Aceh
}

\author{
Azhari Gani ${ }^{1{ }^{1 *}}$ Munifah Abdat ${ }^{2}$ \\ ${ }^{1}$ Faculty of Medicine, Universitas Syiah Kuala, Aceh, Indonesia \\ ${ }^{2}$ Faculty of Dentistry, Universitas Syiah Kuala, Aceh, Indonesia \\ *Corresponding author. Email: azharigani@unsyiah.ac.id
}

\begin{abstract}
Coronary heart disease (CHD) is a condition in which the myocardium does not get enough blood and oxygen supply. Modifiable risk factors for CHD include hypertension and diabetes melitus. This study aims to determine the prevalence of history of hypertension and diabetes melitus in coronary heart disease patients at Regional Government Hospital dr. Zainoel Abidin (RSUDZA) Banda Aceh. A cross sectional study with secondary data collection. The data collection method used retrospective medical records of inpatients at the cardiology department of RSUDZA. Data of 33 patients with coronary heart disease was recorded and analyzed. Results shows the majority of male patients with an age range of 56-65 years. About 51.2\% of CHD patients had a history of hypertension with the highest blood pressure value $>160 / 100 \mathrm{mmHg}$. It was found that $39.4 \%$ of CHD patients had a history of diabetes mellitus with the highest blood sugar value $>200 \mathrm{mg} / \mathrm{dl}$. In conclusion, The prevalence of patients with coronary heart disease at RSUZA mostly had history of hypertension and diabetes mellitus
\end{abstract}

Keywords: Coronary heart disease, diabetes mellitus, hypertension

\section{INTRODUCTION}

Cardiovascular disease is the leading cause of death in the world. One of the cardiovascular diseases is coronary heart disease. As many as 7.1 million people in the world die each year due to coronary heart disease.[1] Coronary heart disease is a condition in which the myocardium does not get an adequate supply of blood and oxygen.[2] The risk factors for CHD are divided into two, namely those that cannot be modified such as age, gender, and family history, and those that can be modified such as hypertension, dyslipidemia, smoking, diabetes mellitus, obesity, and physical inactivity.[3] The results of the 2013 Riskesdas data analysis state that hypertension, diabetes and mental emotional disorders are the dominant risk factors for coronary heart disease.[4]

Data of Riskesdas 2013, the prevalence of coronary heart disease (CHD) in Indonesia based on doctor interviews was obtained as much as $0.5 \%$ of the total population. The prevalence of CHD based on symptoms is $1.5 \%$ of the total population. The province with the highest prevalence of CHD is Central Sulawesi at $0.8 \%$ followed by Aceh province at 0.7\%.[5]
The incidence of CHD in hypertensive patients is more than five times that of normotensive patients. [3] The longer a person suffers from hypertension, the more the risk of coronary heart disease increases.[6] Hypertension can cause heart failure, myocardial infarction, stroke, kidney failure and retinopathy. Hypertension can increase left ventricular resistance which causes the heart's workload to increase and causes heart dilatation. If the process of atherosclerosis continues to occur with age, it will reduce oxygen to the myocardium, while the oxygen demand of the heart increases due to hypertrophy of the ventricles and an increase in the workload of the heart. This will lead to angina or myocardial infarction.[7]

Coronary heart disease (CHD) is the leading cause of mortality and morbidity in patients with type 2 diabetes. According to the American Heart Association in May 2012, at least $65 \%$ of people with diabetes died from heart disease or stroke. In addition, adults with diabetes are two to four times more likely to develop heart disease than people who do not have diabetes.[8],[9] Diabetes mellitus and hypertension are interrelated diseases that predispose an individual to become an atherosclerotic disease.[10], [11] 
Researchers are interested in conducting research on the history of hypertension and diabetes mellitus in coronary heart disease patients because the incidence of coronary heart disease is still high (1.5\%) in Indonesia, especially in Aceh, and similar research data have not been found in Banda Aceh.[5]

\section{RESEARCH METHODOLOGY}

The research was conducted in July - August 2020 at the recording installation of the Regional Government Hospital dr. Zainoel Abidin (RSUDZA) Banda Aceh from December 2019 - August 2020. A cross sectional study with secondary data collection. The data collection method used retrospective medical records of inpatients in 2019. A total of 33 medical record data with a diagnosis of coronary heart disease accompanied by a history of hypertension and diabetes mellitus that met the inclusion and exclusion criteria.

This study passed the ethical clearance committee of the faculty of medicine, syiah kuala university, banda aceh as stated in the letter No. 019/ EA/FK-RSUDZA/ 2020. Data that has been collected was analyzed by frequency distribution using microsoft excel 2016.

\section{RESULT AND REVIEW}

\subsection{Basic Characteristics of Research Subject}

The general characteristics of the subject in this study were grouped by gender, age and profession. Shown in the table 1 , the number of female subject was 12 people $(36.4 \%)$ less than the male subject with a total of 21 people $(63.6 \%)$. In accordance with the research of Windy G. Amisi et al, that Coronary Heart Disease patients are mostly male with a total of 43 subject $(86 \%)$ [12]. In line with the theory of Lewis et al, which says that the morbidity due to CHD in men is greater than in women before women experience menopause, because women have the protective hormone estrogen, but after women experience menopause, the incidence of CHD increases and has the same risk as women. male [13]. It is known that in premenopausal women the protective effect of estrogen on atherosclerotic heart disease is lower and has higher HDL concentrations [14].

Table 1. The age of subject with an age range of 56-65 years dominates the total number of subject, namely 12 people $(36.4 \%)$. In accordance with the research of RF Monica et al, the research subjects were aged $46-65$ years at the time of the study $(84.2 \%)$, group was $>65$ years old $(68 \%)$.
Table 1. Frequency distribution by Gender, Age and Profession

\begin{tabular}{|c|c|c|}
\hline $\begin{array}{c}\text { Characteristics of } \\
\text { Respondent }\end{array}$ & Frequency & $\%$ \\
\hline \multicolumn{3}{|l|}{ Gender } \\
\hline Male & 21 & 63.6 \\
\hline Female & 12 & 36.4 \\
\hline \multicolumn{3}{|l|}{ Age } \\
\hline $26-35$ & 1 & 3 \\
\hline $36-45$ & 5 & 15.2 \\
\hline $46-55$ & 8 & 24.2 \\
\hline $56-65$ & 12 & 36.4 \\
\hline$>65$ & 7 & 21.2 \\
\hline \multicolumn{3}{|l|}{ Profession } \\
\hline Retired & 5 & 15.2 \\
\hline Entrepreneur & 6 & 18.2 \\
\hline Farmer & 5 & 15.2 \\
\hline $\begin{array}{l}\text { Government } \\
\text { employees }\end{array}$ & 8 & 24.3 \\
\hline Housewife & 7 & 21.2 \\
\hline Fisherman & 2 & 6.1 \\
\hline
\end{tabular}

Age is a risk factor for CHD where increasing age will increase the risk of CHD. The older the age, the greater the incidence of plaque that sticks to the walls of blood vessels and causes disruption of blood flow through it.[16]

Based on the respondent's profession, in table 1 , the number of Civil Servants (PNS) that dominates is as many as 8 people $(24.3 \%)$. The results of A Farahdika et al research showed that there was no relationship between type of work and coronary heart disease. The type of work is related to the respondent's activity level [16]. Meanwhile, according to the results of Desy Diastutik's research, it shows that most subject with coronary heart disease are retired or not working, in contrast to subject with non-coronary heart disease, most of whom have jobs. Someone who works can also be said to do physical activity. This physical activity can be used as an effort to train the heart muscle so that the heart can pump blood better. Regular and sufficient physical activity can also remove fatty deposits that have accumulated on the walls of blood vessels so as to facilitate blood flow to and from the heart. A person who does work can even fulfill about $30 \%$ of the total physical activity he needs.[17] 


\subsection{Distribution Based on History of Hypertension and Blood Pressure}

The following is the distribution of history of hypertension and blood pressure values of CHD patients at the Cardiac Section of RSUDZA Banda Aceh.

Table 2. Frequency distribution on History of Hypertension and Blood Pressure

\begin{tabular}{|c|c|c|}
\hline $\begin{array}{c}\text { Characteristics of } \\
\text { Respondent }\end{array}$ & Frequency & $\%$ \\
\hline $\begin{array}{l}\text { History of } \\
\text { Hypertension }\end{array}$ & 25 & 75.8 \\
\hline Yes & 8 & 24.2 \\
\hline No & 3 & \\
\hline Blood Pressure & 6 & 9.1 \\
\hline$<120 / 80$ & 7 & 18.2 \\
\hline $120-139 / 80-89$ & 17 & 21.2 \\
\hline $140-159 / 90-99$ & & 51.5 \\
\hline$>160 / 100$ & & \\
\hline
\end{tabular}

In table 2, respondents with a history of hypertension are 25 people $(75.8 \%)$, and those who are not are 8 people $(24.2 \%)$ and the highest blood pressure value is $>160 / 100$ is 17 people $(51.2 \%)$. . These results indicate that CHD patients with a history of hypertension have blood pressure $>160 / 100 \mathrm{mmHg}$. These results are in accordance with Mentari's 2017 research on 46 inpatients at RSUD Dr. M. Yunus Bengkulu found a high prevalence of CHD (100\%), and there was a relationship between hypertension and CHD [18]. D Zahrawardani's research at Dr Kariadi Hospital Semarang also found a relationship between hypertension and coronary heart disease [19].

Different from the results of Danivan Fajari's study, there was no relationship between hypertension and the severity of coronary heart disease based on the Sullivan vessel score. In the study it was said that other risk factors showed a greater relationship in assessing the severity of coronary heart disease, including age, diabetes, hyperlipidemia, and gender.[20]

\subsection{Distribution Based on History of Diabetes Mellitus and Current Blood Sugar}

The following is the distribution of history of diabetes mellitus and current blood sugar values of CHD patients at the Cardiac Section of RSUDZA.
Table 3. Frequency distribution on History of Diabetes Mellitus and Current Blood Sugar

\begin{tabular}{|c|c|c|}
\hline $\begin{array}{c}\text { Characteristics of } \\
\text { Respondent }\end{array}$ & Frequency & $\%$ \\
\hline $\begin{array}{l}\text { History of } \\
\text { Hypertension }\end{array}$ & 17 & 51.5 \\
\hline Yes & 16 & 48.5 \\
\hline No & 8 & 24.2 \\
\hline Current Blood Sugar & 13 & 39.4 \\
\hline$<200$ & 12 & 36.4 \\
\hline$>200$ & & \\
\hline No Found & & \\
\hline \multicolumn{2}{|c|}{} \\
\hline
\end{tabular}

Table 3 shows that the description of patients with a history of DM is more than $17(51.5 \%)$ people, while the highest blood sugar value is $>200$ as many as 13 people (39.4\%). This shows that CHD patients with diabetes mellitus have blood sugar values $>200$. The results of this study are in line with the research of Budiman et al (2015), where the number of CHD patients with diabetes mellitus was obtained as many as 63 people $(88.7 \%)$ [21]. In the research of M Husni et al, it was also found that diabetes mellitus had a 2.1-fold effect on the incidence of CHD [22].

In addition, in the research results of Nur Lisa Utami et al, it was found that there are several variables that influence the incidence of CHD in patients with diabetes mellitus, namely in the form of variables age, length of suffering from DM and history of hypertension affecting the incidence of CHD in DM patients. The most dominant variable associated with the incidence of CHD in DM patients is a history of obesity [23].

\section{CONCLUSION}

The prevalence of patients with coronary heart disease at RSUZA mostly had history of hypertension and diabetes mellitus. It was found that most CHD patients had a history of hypertension with blood pressure values $>160 / 100 \mathrm{mmHg}$ and blood sugar values $>200 \mathrm{mg} / \mathrm{dl}$.

\section{ACKNOWLEDGMENTS}

The author would like to thank the Chemistry Laboratory of the Regional Government Hospital dr. Zainoel Abidin (RSUDZA) Banda Aceh for permission and for facilitating this research process. 


\section{REFERENCES}

[1] WHO. Cardiovaskular Disease (CVDs) [Internet]. 2017 [cited 2019 Mar 29]. Available from: https://www.who.int/news$\mathrm{room} /$ detail/cardiovascular-diseases-(cvds)

[2] Liwang F, Wijaya IP. Penyakit Jantung Koroner. In: Tanto C, Liwang F, Hanifati S, Pradikta EA, editors. Capita Selecta Medicine. IV. Jakarta: Media Aesculapius; 2016. p. 74855.

[3] Libby P. The Pathogenesis, Prevention, and Treatment of Atherosclerosis. In: Harrison's Principle of Internal Medicine. 17th ed. United States of America: McGraw-Hill; 2008. p. $1501-9$.

[4] Ghani L, Susilawati MD, Novriani H. Faktor Risiko Dominan Coronary Heart Disease in Indonesia. Bul Penelit Kesehat. 2016;44(3):153-64.

[5] Health Research and Development Agency of the Indonesian Ministry of Health. Basic Health Research. Jakarta; 2013.

[6] Irwan IDN\& FU\&. Effect of Long Hypertension on Coronary Heart Disease in Cardiology Polyclinic RSUP . Dr. Mohammad Hoesin Palembang 2012. J Kedokt dan Kesehat. 2014;1(1):55-60.

[7] Price sylvia A, Wilson LMC. Pathophysiology: Clinical Concepts of Disease Processes. 6th ed. Jakarta: EGC; 2012.

[8] Association AH. Lifestyle Changes for Heart Attack Prevention. American Heart Association. 2018.

[9] Riddle MC. American Diabetes Association Standards of Medical Care in Diabetes 2018. Am Diabetes Assoc. 2018;41(1):1-155.

[10] International Diabetes Federation (IDF). IDF Diabetes Atlas Sixth Edition. IDF; 2013.p.1-160

[11] M N Piero, G M Nzaro, J M Njagi. Diabetes Melitus-A Devastating Metabolic Disorder. Asian J Biomed Pharm Sci. 2014;4(40):1-7.

[12] Amisi WG, Nelwan JE, Kolibu FK. The Relationship Between Hypertension And The Incidence Of Coronary Heart Disease In Patients Treating At Prof. Central General Hospital. Dr. R.D. Kandou Manado. J Kesmas 2018;7(4):1-7.
[13] Sharon Lewis, Linda Bucher, Margaret Heitkemper, Mariann Harding, Jeffrey Kwong, Dottie Roberts. Medical-Surgical Nursing. St.Luuis Missouri: Elsevier; 2016.

[14] Setiawan A, Panggabean M, Yamin M, Setiati S. Five-Year Survival of Three Vessel Coronary Heart Disease Patients with Diabetes Mellitus Undergoing Coronary Bypass Surgery, Percutaneous Coronary Intervention or Medical Treatment at dr. Cipto Mangunkusumo. $J$ Penyakit Dalam Indones. 2017;3(2):60.

[15] Monica RF, Adiputro DL, Marisa D. Relationship between hypertension and coronary heart disease in heart failure patients at Ulin Hospital Banjarmasin. Homeostasis. 2019;2(1):121-4.

[16] Farahdika, A. And AZAM M.Kes., dr. M. 2015 Risk Factors Associated with Coronary Heart Disease in Middle Adult Age 41-60 Years (Case Study in Semarang City General Hospital). Unnes Journal of Public Health. 4, 2 (Apr. 2015).

DOI:https://doi.org/10.15294/ujph.v4i2.5188

[17] Desy Diastutik. 2016. The proportion of characteristics of coronary heart disease patients in active smokers based on smoking characteristics. Jurnal Berkala Epidemiologi. 4. 3, (September 2016). 326-337

[18] Mentari S. The relationship between hypertension and coronary heart disease in inpatients at RSUP DR. M. Yunus Bengkulu. Tesis. Univ Bengkulu. 2017;

[19] Zahrawardani D, Herlambang KS, Anggraheny HD. Analysis of Risk Factors for Coronary Heart Disease at Dr Kariadi Hospital, Semarang. $J$ Kedokt Muhammadiyah [Internet]. 2013;1(3):13. Available from http://jurnal.unimus.ac.id/index.php/kedokteran/ article/view/1341

[20] Danivan Fajari Ramandityo. Relationship of Hypertension with Severity of Coronary Heart Disease Based on Sullivan Vessel Score. Skripsi. FK UIN Syarif Hidayatullah. 2016;

[21] Budiman B, Sihombing R, Pradina P. 2015. Correlation Between Dyslipidemia, Hypertension And Diabetes Mellitus With Acute Myocardial Infarction On Ward Inpatient. JKMA. 10. 1. 32-33 
[22] Husni M, Lapau B, Hardhana B. The Relationship between Dyslipidemia and Diabetes Mellitus with the Incidence of Coronary Heart Disease at the Regional Hospital. Caring Nurs J. 2018;2(2):66-9.

[23] Utami NL, Azam M. The incidence of coronary heart disease in patients with diabetes mellitus.. HIGEIA (Journal Public Heal Res Dev). 2019;3(2):311-23 